\title{
SUITABILITY STUDY OF USING BIRCH AND WILLOW TREES IN PHYTOREMEDIATION OF ACIDIC WASTE SETTLERS
}

\section{Elżbieta JAROSZ-KRZEMIŃSKA \& Ewa ADAMIEC}

\author{
AGH University of Science and Technology, Faculty of Geology, \\ Geophysics and Environmental Protection; \\ al. Mickiewicza 30; 30-059 Krakow, Poland; \\ e-mail:elzbietajarosz@geol.agh.edu.pl
}

\begin{abstract}
Research addresses the issue of assessing the possibility of using birch and willow trees in phytoremediation of acidic waste settlers. In order to determine the suitability of these trees to bioaccumulate metals it was crucial to first characterized the physico-chemical parameters of the waste. Both waste and leaves samples were analyzed with respect to heavy metals concentration using microwave digestion (conc. $\mathrm{HNO}_{3}$ ) procedure followed by AAS analyzes. Moreover, the mobility of contaminants from waste was studied using aqueous leaching test as well as sequential extraction procedures. Investigated waste is very inhomogeneous and is characterized with diversity of $\mathrm{pH}$ values within sampling points (2.9-7.0) as well as with high concentration of $\mathrm{SO}_{4}^{2-}$ anions $\left(1203-1301 \mathrm{mg} / \mathrm{dm}^{3}\right)$, Fe (11-19\%) and $\mathrm{Zn}(64-172 \mathrm{mg} / \mathrm{kg})$. Ability to accumulate metals in birch and willow leaves is high. In birch leaves $\mathrm{Zn}$ was accumulated up to toxic level of $431 \mathrm{mg} / \mathrm{kg}$, Mn up to $790 \mathrm{mg} / \mathrm{kg}, \mathrm{Cu}$ up to $9 \mathrm{mg} / \mathrm{kg}, \mathrm{Pb}$ up to $21 \mathrm{mg} / \mathrm{kg}$. In willow leaves $\mathrm{Zn}$ concentration were found to be even higher and reached $679 \mathrm{mg} / \mathrm{kg}$. Concentrations of remaining metals in willow leaves were as follows: Mn up to $173 \mathrm{mg} / \mathrm{kg}, \mathrm{Cu}$ up to $17 \mathrm{mg} / \mathrm{kg}$ and $\mathrm{Pb}$ up to $10 \mathrm{mg} / \mathrm{kg}$. Research results confirmed that both birch and willow trees growing on settlers have high tolerance to the adverse living conditions caused by metal stress and low $\mathrm{pH}$ of the foundation. These trees can be used for the purpose of phytoremediation of investigated waste settlers.
\end{abstract}

Key words: settler, acidic wastes, bioaccumulation, heavy metals, phytoremediation 


\section{INTRODUCTION}

Reclamation of contaminated sites requires a combination of both technical and biological reclamation. Technical reclamation involves mainly leveling of the deposited material, isolating it with proper layer and applying topsoil. Biological remediation is based on planting vegetation on prepared foundation. Phytoremediation is a common solution applied to waste management due to relatively low cost, minimal impact on the environment, and effective results. It is one of the alternative methods of remediation of postindustrial and degraded sites, by using higher plants and their associated microorganisms to remove or immobilize both organic and inorganic contaminants. Creation of the vegetal layer besides improving the aesthetics of the destroyed landscape, has other tangible benefits such as stabilization of the waste surface and protection against wind and water erosion.

Phytoremediation techniques involves phytoextraction, phytostabilization, phytodegradation, phytovolatilization and rhizofiltration (Alkorta et al. 2004, Kacprzak 2007). The most commonly methods applied for the purpose of remediation of heavy metals contaminated sites are phytoextraction and phytostabilization.

Industrial waste due to its physico-chemical characteristics is difficult and often extreme environment for plants (Tordoff et al. 2000). Selection of proper vegetation for the purpose of phytoremediation is crucial. Plants must be chosen adequately to the properties of the foundation. The basic criteria for the selection of plants for phytoremediation of degraded sites area are according to Kacprzak (2007): resistance to contamination, the ability to accumulate as many metals as possible and rapid growth of plants. In addition, the knowledge of the vegetation in the close vicinity of the contaminated site is very useful since these plants can be a potential source of diaspora for the future formation of independently functioning ecosystem (Urbańska et al. 1997, Szarek-Łukaszewska et al. 2009).

The central point of interest is an area of 1.62 ha which comprises of two settlers of acidic waste which have originated from steel manufacture as a result of pickling steel with sulfuric acid. Post processed solutions, containing mostly iron sulfide and iron sulfate were neutralized by lime suspension and in form of sludge deposited into lagoons. In 1993 generating and dumping of these acidic waste have stopped. Waste producer is obliged by law to resolve problem of deposited waste by either utilization or by reclaiming the site.

In some areas within the waste settlers birch and willow trees are present, while no such type of flora may be found in the surrounding vicinity. In the study these two types of trees were analysed for their potential use in the process of settlers reclamation. The aim of the study was to (1) characterize physico-chemical parameters of waste and the mobility of contaminants and to (2) check ability of birch and willow leaves to accumulate metals in their leaves.

\section{SAMPLING AND METHODS}

Waste samples were taken from six sampling points, from which three were located in close vicinity to birch and willow trees and other three samples were taken from places with no vegetation. Furthermore, birch and willow leaves were collected every month for 
six month (from June to November) from three sampling points in order to check variability in metals intake during different seasons.

Waste and leaves samples were analyzed for the heavy metal concentrations. In order to assess complete chemical characterization of waste, physical-chemical parameters i.e. $\mathrm{pH}$, Eh, electrolytic conductivity and total concentration of metals were determined. Moreover buffer capacity of waste was established by performing acid titration procedure. Furthermore in order to reveal the mobility of contaminants in waste and its potential bioavailability to plants aqueous leaching test and sequential extraction procedure were applied. Aqueous leaching test was conducted according to Polish regulations PN-EN 12457-2 compliant to EU standard.

Ion chromatography was used to determine the concentrations of main anions in waste samples. Waste samples were dried in $105^{\circ} \mathrm{C}$ and digest in the microwave with concentrated nitric acid according to modified SW 3051 EPA procedure. Leaves were first lyophilized and afterwards were treated with the same digestion procedure as waste samples. The metal concentrations were determined with AAS method.

\section{RESULTS AND DISCUSSION}

\section{Physico-chemical characteristics of waste}

Waste deposited in the settlers is fine grained and uniform with strong orange color derived from high iron content. In deeper sections of waste white layers are present which indicates the presence of gypsum. Investigation has shown that $\mathrm{pH}$ and $\mathrm{Eh}$ values varied significantly within sampling points. $\mathrm{pH}$ values of the waste ranged from acidic ( $\mathrm{pH} 2.9$ ) to neutral ( $\mathrm{pH} \mathrm{7)}$ (Tab. 1). In places where trees occurred (sampling points O1,O2, O3), $\mathrm{pH}$ values were showing slightly acidic (4.5) to neutral conditions (6.9), however in sampling points with no vegetation $(\mathrm{O} 4, \mathrm{O} 5, \mathrm{O} 6) \mathrm{pH} \sim 3$ reflects strong acidic conditions. Moreover, also Eh values changed significantly within sampling points (31-200 mV), showing weak reducing to oxidizing conditions. Places with vegetation were found to have reducing conditions and consequently sampling points with low $\mathrm{pH}$ and no vegetation were presenting oxidizing conditions. The electrolytic conductivity has not revealed any changes within sampling points and ranged between $3-4 \mathrm{mS} / \mathrm{cm}$ in all measured waste samples both with and without vegetation.

The results of acid titration experiments for the selected, most representative waste suspensions are presented in Figure 1A. Results exhibit a plateau in the $\mathrm{pH}$ of 4 and 5 for the waste sample of neutral $\mathrm{pH} \mathrm{7,} \mathrm{probable} \mathrm{due} \mathrm{to} \mathrm{presence} \mathrm{of} \mathrm{small} \mathrm{calcium} \mathrm{carbonate}$ amount which is consumed by the addition of nitric acid. After addition of the first acid portion, $\mathrm{pH}$ dropped from 7.0 to 5.3 showing the good buffer capacity. Addition of the next two portions of acid resulted in decrease of $\mathrm{pH}$ by 0.9 unit. In waste sample of $\mathrm{pH} 4.3$ the first 
addition of acid caused decrease of $\mathrm{pH}$ below 2, therefore indicating intermidiate buffer capacity. However in the waste sample of $\mathrm{pH} 6.3$ the first addition of acid caused decrease of $\mathrm{pH}$ to 2.03 indicating lack of buffering substances in that waste sample.

Table 1

Physico-chemical parameters of waste and aqueous leachates from waste

\begin{tabular}{|c|c|c|c|c|c|c|}
\hline \multirow{2}{*}{ Parameter } & \multicolumn{6}{|c|}{ Metal concentration in waste samples } \\
\hline & O1 & $\mathrm{O} 2$ & $\mathrm{O} 3$ & $\mathrm{O} 4$ & O5 & O6 \\
\hline $\mathrm{Cu}[\mathrm{mg} / \mathrm{kg}]$ & 18 & 16 & 23 & 23 & 20 & 18 \\
\hline $\mathrm{Zn}[\mathrm{mg} / \mathrm{kg}]$ & 172 & 144 & 72 & 89 & 114 & 64 \\
\hline $\mathrm{Pb}[\mathrm{mg} / \mathrm{kg}]$ & 37 & 27 & 46 & 33 & 43 & 34 \\
\hline $\mathrm{Mn}[\mathrm{mg} / \mathrm{kg}]$ & 95 & 204 & 66 & 103 & 118 & 185 \\
\hline $\mathrm{Fe}[\%]$ & 15 & 14 & 11 & 16 & 17 & 19 \\
\hline $\mathrm{pH}$ & 6.3 & 7.0 & 4.5 & 2.9 & 3.2 & 3.1 \\
\hline $\mathrm{PEW}[\mathrm{mS} / \mathrm{cm}]$ & 3.4 & 3.3 & 3.3 & 3.7 & 4.0 & 4.0 \\
\hline $\mathrm{Eh}[\mathrm{mV}]$ & -25 & -31 & 145 & 199 & 200 & 198 \\
\hline \multirow{2}{*}{ Parameter } & \multicolumn{6}{|c|}{ Metal concentration in aqueous leachates $\left[\mathrm{mg} / \mathrm{dm}^{3}\right]$} \\
\hline & O1 & $\mathrm{O} 2$ & $\mathrm{O} 3$ & $\mathrm{O} 4$ & O5 & O6 \\
\hline $\mathrm{Cu}(0.5)^{*}$ & b.d.1. & 0.06 & 0.07 & 0.03 & 0.05 & 0.03 \\
\hline $\mathrm{Zn}(2)$ & 0.01 & 0.00 & 0.30 & 2.45 & 4.89 & 1.51 \\
\hline $\mathrm{Pb}(0.5)$ & 0.04 & 0.08 & 0.12 & 0.08 & 0.00 & 0.08 \\
\hline $\operatorname{Mn}(-)$ & 0.00 & 0.00 & 0.57 & 0.46 & 0.11 & 0.33 \\
\hline $\mathrm{Fe}(10)$ & 0.08 & 0.08 & 0.00 & 2.16 & 0.08 & 0.08 \\
\hline $\mathrm{F}^{-}(25)$ & 1.92 & 2.11 & 2.15 & 3.17 & 2.01 & 0.09 \\
\hline $\mathrm{Cl}^{-}(1000)$ & 1.34 & 2.27 & 1.62 & 5.37 & 0.87 & 0.66 \\
\hline $\mathrm{NO}_{3}^{-}(30)$ & 1.91 & 2.80 & 5.47 & 12.32 & 1.78 & 4.76 \\
\hline $\mathrm{SO}_{4}^{2-}(500)$ & 1263 & 1207 & 1238 & 1253 & 1301 & 1300 \\
\hline $\mathrm{pH}$ & 7.1 & 7.0 & 4.1 & 3.2 & 3.2 & 3.2 \\
\hline
\end{tabular}

b.d.1. - below detection limit

()* - maximum permissible values according to Dz.U. 2006, nr 137, poz. 984

$\mathrm{O} 1-\mathrm{O} 3$ - waste samples taken from places with vegetation

O4-O6 - waste samples taken from places without vegetation

Concentration of metals in waste, presented in Table 1 revealed very high content of Fe (11-19 wt. \%) in all investigated samples. Furthermore, with respect to other examined metals the concentrations were found to be (mg/kg): 66-204 for Mn, 27-46 for $\mathrm{Pb}, 64-172$ for $\mathrm{Zn}$ and 16-23 for $\mathrm{Cu}$. 


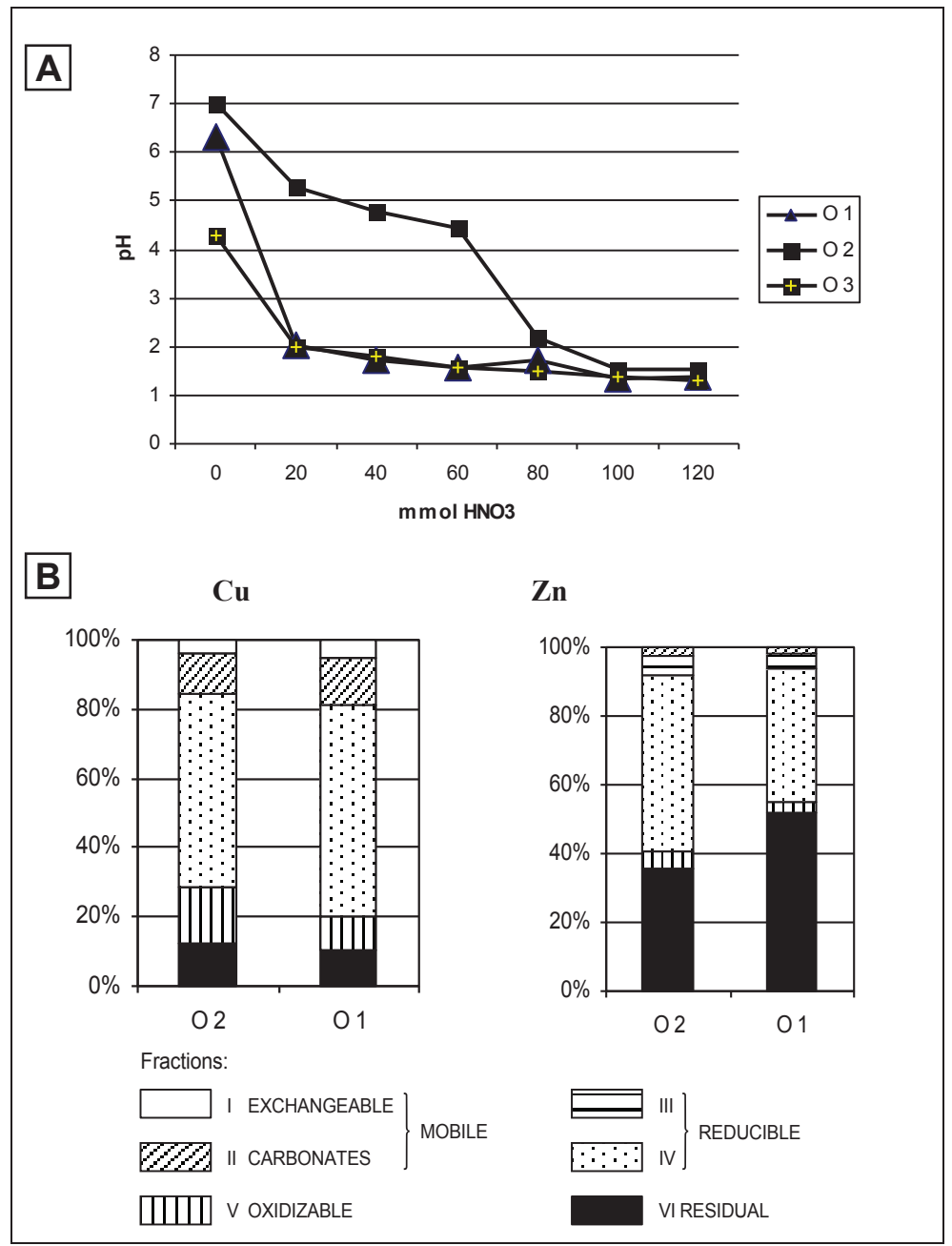

Fig. 1. Buffering capacity of waste (A) and sequential extraction results for selected waste samples (B)

\section{Mobility of contaminants in waste}

Mobility of the contaminants in waste were determined by aqueous leaching test and sequential extraction procedure. As indicated by many authors (Tessier et al. 1979, Dold 2003, Bettiol et al. 2008) these methods are commonly used in environmental analysis in the study of bioavailability and mobility of elements present in the soil and sediment systems.

For the aqueous leaching test a suspension of 1:10 solid/liquid ratio was prepared as a procedure in this protocol, and $\mathrm{pH}$ of obtained solutions were measured immediately. 
Two groups of waste samples were distinguished according to $\mathrm{pH}$ values, neutral samples ( $\mathrm{pH} 7.11-7.08)$ and of acidic ones ( $\mathrm{pH} 3.21-4.14)$. Table 1 summarizes $\mathrm{pH}$ and the metal concentrations in the studied waste leachates. Results revealed that $\mathrm{Cu}$ was released up to $0.07 \mathrm{mg} / \mathrm{dm}^{3}, \mathrm{Zn}$ up to $4.89 \mathrm{mg} / \mathrm{dm}^{3}, \mathrm{~Pb}$ up to $0.12 \mathrm{mg} / \mathrm{dm}^{3}, \mathrm{Mn}$ up to $0.57 \mathrm{mg} / \mathrm{dm}^{3}$ and Fe was leached out up to $2.16 \mathrm{mg} / \mathrm{dm}^{3}$. In order to detect anions concentrations in aqueous solutions of the waste Ion Chromatography was used. Leachates of all waste samples revealed high concentration of $\mathrm{SO}_{4}^{2-}$ ions $\left(1207-1300 \mathrm{mg} / \mathrm{dm}^{3}\right)$, whereas other examined anions $\mathrm{Cl}^{-}$, $\mathrm{NO}_{3}{ }^{-}$and $\mathrm{F}^{-}$were detected at low levels. Results has shown that only $\mathrm{Zn}$ and $\mathrm{SO}_{4}{ }^{2-}$ concentration were exceeding maximum permissible values allowed to be introduced to the environment according to Polish Directive Dz.U. 2006, nr 137, poz. 984.

Results of sequential extraction carried out for two selected waste samples, showed that $40-55 \%$ of total $\mathrm{Zn}$ was associated with the reducible fractions and almost the same portions with residuum (Fig. 1B). In both studied waste samples almost $60 \%$ of Cu was combined with reducible fraction and about $30 \%$ of this metal was distributed between carbonatic and oxidizable fractions.

The results have shown that about $90 \%$ of total $\mathrm{Zn}$ is bounded with relatively stable forms, i.e. Fe-ox-hydroxides and residuum. It seems that because of very high iron content in the studied acidic wastes, its considerable portion are not extractable in the reducible fraction but in residuum. Hence the relative high portion of stable $\mathrm{Zn}$ was found also in the residuum, probably combined with Fe-oxides.

\section{Concentration of metals in plants}

Results of metal concentrations in birch and willow leaves growing on settlers are present in Figure 2 and Table 2. Concentrations of selected metals were compared to standard concentrations of metals in various plants, according Kabata-Pendias \& Pendias (1999). Results have shown that $\mathrm{Zn}$ concentration in all birch and willow samples were elevated when compared with standard values. According to Pendias \& Pendias (1999) upper toxic level of $\mathrm{Zn}$ in various plants is reported to be between range $100-400 \mathrm{mg} / \mathrm{kg}$, and normal or sufficient level ranges between $25-150 \mathrm{mg} / \mathrm{kg}$. In all investigated leaves from the settlers $\mathrm{Zn}$ concentrations were found to exceed the excessive or toxic concentration and ranged from $156 \mathrm{mg} / \mathrm{kg}$ to $431 \mathrm{mg} / \mathrm{kg}$ in birch leaves and $181-679 \mathrm{mg} / \mathrm{kg}$ in willow leaves. Particularly high $\mathrm{Zn}$ bioavailability was observed in one willow sample, where its concentration was found to be $679 \mathrm{mg} / \mathrm{kg}$, exceeding threshold value over four times. However as indicated by Kabata-Pendias \& Pendias (1999), most plant species and genotypes have great tolerance to excessive amount of $\mathrm{Zn}$ and its phytotoxicity is reported relatively often, especially for acid soils. An excess of $\mathrm{Zn}$ lead to reduction in Fe concentration in plants. Moreover, Fe could decrease $\mathrm{Zn}$ absorption and its toxicity, probably because of the competition between $\mathrm{Zn}^{2+}$ and $\mathrm{Fe}^{2+}$ ions in the uptake processes. Concentrations of other metals $\mathrm{Cu}, \mathrm{Mn}, \mathrm{Pb}$ in all investigated leaves from birch and willow were not elevated when compared with threshold values in Table 2 meeting sufficient or normal level accepted for the plants. 


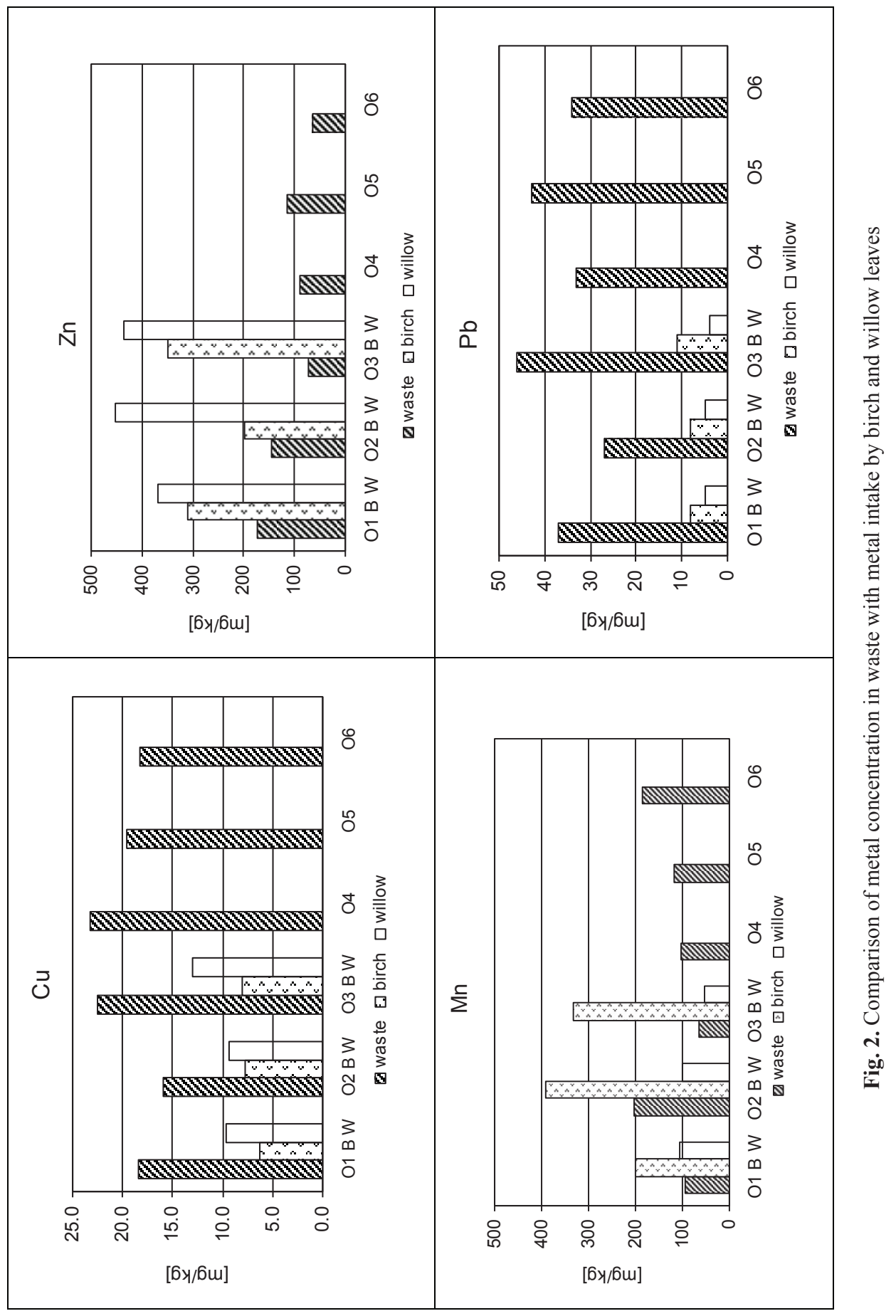


Table 2

Concentration of metals in willow and birch leaves (collected from June to October)

\begin{tabular}{|c|c|c|c|c|}
\hline \multirow{2}{*}{ Sample } & \multicolumn{4}{|c|}{ Metal concentration in birch and willow leaves $[\mathrm{mg} / \mathrm{kg}]$} \\
\hline & $\mathrm{Mn}$ & $\mathrm{Zn}$ & $\mathrm{Cu}$ & $\mathrm{Pb}$ \\
\hline W1 VI & 51 & 181 & 12 & 1 \\
\hline W1 VII & 173 & 416 & 11 & 2 \\
\hline W1 VIII & 66 & 322 & 8 & 6 \\
\hline W1 IX & 93 & 475 & 8 & 8 \\
\hline W1 X & 145 & 446 & 9 & 10 \\
\hline Mean & 106 & 368 & 10 & 5 \\
\hline W2 VI & 102 & 328 & 12 & 2 \\
\hline W2 VII & 86 & 286 & 9 & 3 \\
\hline W2 VIII & 49 & 304 & 11 & 7 \\
\hline W2 IX & 129 & 618 & 8 & 6 \\
\hline W2 X & 134 & 721 & 8 & 10 \\
\hline Mean & 100 & 451 & 9 & 5 \\
\hline W3 VI & 46 & 252 & 17 & 1 \\
\hline W3 VII & 46 & 325 & 15 & 1 \\
\hline W3 VIII & 60 & 485 & 12 & 5 \\
\hline W3 IX & 60 & 679 & 12 & 6 \\
\hline W3 X & 50 & 418 & 7 & 7 \\
\hline Mean & 52 & 432 & 13 & 4 \\
\hline B1 VI & 171 & 252 & 6 & 4 \\
\hline B1VII & 93 & 218 & 7 & 5 \\
\hline B1 VIII & 183 & 254 & 7 & 7 \\
\hline B1 IX & 253 & 398 & 6 & 11 \\
\hline B1 X & 295 & 427 & 6 & 12 \\
\hline Mean & 199 & 310 & 6 & 8 \\
\hline B2 VI & 276 & 161 & 7 & 5 \\
\hline B2 VII & 246 & 156 & 6 & 6 \\
\hline B2 VIII & 255 & 148 & 5 & 7 \\
\hline B2 X & 790 & 329 & 8 & 13 \\
\hline
\end{tabular}


Table 2 cont.

\begin{tabular}{|c|c|c|c|c|}
\hline Mean & 392 & 198 & 7 & 8 \\
\hline B3 VI & 299 & 407 & 9 & 5 \\
\hline B3 VII & 390 & 374 & 8 & 8 \\
\hline B3 VIII & 266 & 220 & 7 & 10 \\
\hline B3 IX & 308 & 307 & 8 & 11 \\
\hline B3 X & 391 & 431 & 9 & 21 \\
\hline Mean & 331 & 348 & 8 & 11 \\
\hline $\begin{array}{c}\text { Physiological concentration } \\
\text { in plants [mg/kg] }\end{array}$ & $30-300$ & $25-150$ & $5-30$ & $5-10$ \\
\hline $\begin{array}{c}\text { Toxic concentration } \\
\text { in plants [mg/kg] }\end{array}$ & $400-1000$ & $100-400$ & $20-100$ & $30-300$ \\
\hline
\end{tabular}

* According to Kabata-Pendias \& Pendias (1999)

W1, W2, W3 - willow from $1^{\text {st }}, 2^{\text {nd }}, 3^{\text {rd }}$ sampling points

B, B2, B3 - birch from $1^{\text {st }}, 2^{\text {nd }}, 3^{\text {rd }}$ sampling points

VI-X - month in which leave samples were collected

Moreover there was a great variation observed in metal concentrations in leaves of both trees in relation to the month in which samples were collected. Higher concentrations of metals in leaves were detected in October and November than in summer months, which was probably related to greated amount of precipitation during these periods.

\section{CONCLUSIONS}

Research results indicate that low $\mathrm{pH}$ of investigated waste and high concentration of sulfate anions can be potentially harmfull for trees growing on the settlers. However, an analysis revealed that high iron content control heavy metals mobilization. Furthermore, sorption of heavy metals is evoked by the presence of iron ox-hydroxides, which posses relatively high specific surface area, sorption capacity as well as good buffer capacity. Both birch and willow trees growing on the settlers revealed high tolerance to adverse living conditions caused by metal stress and low $\mathrm{pH}$ of the waste. Ability of these trees' leaves to accumulate metals from wastes is high. Both birch and willow are accumulating an elevated concentration of metals, especially $\mathrm{Zn}$, which was detected at toxic levels. The results therefore confirm the reports of other authors e.g. Pulford \& Watson (2003), Chaney (1998) and Dickinson (2000) about the suitability of birch and willow trees in phytoremediation of contaminated sites.

This work has been supported by the Faculty of Geology, Geophysics and Environmental Protection at the AGH University of Science and Technology in Krakow. 


\section{REFERENCES}

Alkorta I., Hernández-Allica J., Becerril J., Amezaga I., Albizu I. \& Garbisu C., 2004. Recent findings on the phytoremediation of soils contaminated with environmentally toxic heavy metals and metalloids such as zinc, cadmium,lead, and arsenic. Reviews in Environmental Science and Bio/Technology, 3, 71-90.

Bettiol C., Stievano L., Delfini F. \& Argese E., 2008. Evaluation of microwave assisted acids extraction procedures for the determination of metal content and potential bioavailability in sediments. Applied Geochemistry, 23, 1140-1151.

Chaney R., Malik M., Li Y.M., Brown S.L., Brewer E.P., Angle J.S. \& Baker A.J.M., 1998. Phytoremediation of soil metals. Current Options in Biotechnology, 8, 279-284.

Dickinson N.M., 2000. Trees as environmental sentinels. Biologist, 47, 211-215.

Dold B., 2003. Speciation of the most soluble phases in a sequential extraction procedure adapter for geochemical studies of copper sulfide mine waste. Journal of Geochemical Exploration, 80, 55-68.

Kabata-Pendias A. \& Pendias H., 1999. Biochemia pierwiastków śladowych. Wydawnictwo Naukowe PWN, Warszawa.

Kacprzak M., 2007. Wspomaganie procesów remediacji gleb zdegradowanych. Monografie - Politechnika Częstochowska 128, Wydawnictwo Politechniki Częstochowskiej, Częstochowa.

Pulford I.D. \& Watson C., 2003. Phytoremediation of heavy metal contaminated land by trees a review. Environment International, 29, 529-540.

Szarek-Łukaszewska G., Ryszka P. \& Zarszyka-Ryszka M., 2009. Rekultywacja odpadów $\mathrm{Zn} / \mathrm{Pb}$ - metody ekologiczne - eksperyment terenowy. [in:] Ozonek J. \& Pawłowski A. (red.), Polska inżynieria środowiska pięć lat po wstąpieniu do Unii Europejskiej, 2, Komitet Inżynierii Środowiska PAN, Lublin, 219-223.

Tessier A., Campbell P.G.C. \& Bisson M., 1979. Sequential extraction procedure for speciation of particulate trace metals. Analytical Chemistry, 51, 844-851.

Tordoff G.M., Backer A.J.M. \& Willos A.J., 2000. Current approaches to the revegetation and reclamation of metaliferous mine wastes. Chemosphere, 41, 219-228.

Urbańska K.M., Webb N.R. \& Edwaerd P.J., 1997. Restoration ecology and sustainable development. Cambridge University Press. 